\title{
Sensory and microbiological evaluation of uncured fresh chicken sausage with reduced fat content
}

\author{
Avaliação sensorial e microbiológica de linguiça de frango frescal não curada com reduzido teor de gordura
}

\author{
Anna Cecilia VENTURINI ${ }^{1 *}$, Ângela Dulce CAVENAGHI ${ }^{2}$, \\ Carmen Josefina Contreras CASTILLO ${ }^{3}$, Eliane Marta QUIÑONES ${ }^{4}$
}

\begin{abstract}
The purpose of this study was to evaluate the acceptability and the microbiological safety of uncured fresh chicken sausages with reduced fat content, considering the scientific evidence that correlated cancer and cardiovascular diseases to this diet. Two formulations of uncured fresh chicken sausage were processed using different concentrations of cochineal carmine pigment, rosemary extracts and synthetic antioxidants, which are used to give color, appearance and pleasant flavor to the products. Then, instrumental color $\left(\mathrm{L}^{*}, \mathrm{a}^{\star}, \mathrm{b}^{*}, \mathrm{C}^{\star}\right.$ and $\left.\mathrm{h}^{\star}\right)$, microbial contamination and sensory tests (ranking and acceptance) were used to evaluate the quality of the uncured chicken sausages. The instrumental color (chroma and hue) and the sensory properties of the A and B uncured sausages were similar to the commercial cured sausage (C). However, the sensory color and appearance of samples A and B were statistically higher than those of the commercial uncured sausages D, which are prepared without the addition of nitrite or pigments. The results showed that it is possible to produce safe and high-quality uncured fresh chicken sausage with reduced fat content, using natural pigments and antioxidants.

Keywords: centesimal composition; instrumental color; acceptance test; salmonella; clostridium.
\end{abstract}

\section{Resumo}

O objetivo deste trabalho foi avaliar a aceitabilidade e a segurança microbiológica de linguiça de frango frescal não curada formulada com baixo teor de gordura, considerando as evidências científicas que correlacionam câncer e doenças cardiovasculares à dieta. Duas formulações de linguiça frescal de frango foram processadas, usando diferentes concentrações de carmim cochonilha, extrato de alecrim e antioxidantes sintéticos utilizados para dar cor, aparência e sabor agradáveis aos produtos. Então, a cor instrumental $\left(\mathrm{L}^{\star}, \mathrm{a}^{*}, \mathrm{~b}^{\star}, \mathrm{C}^{\star} \mathrm{e} \mathrm{h}^{\star}\right)$, contaminação microbiana e testes sensoriais (ordenação-preferência e aceitação) foram utilizados para avaliar a qualidade das linguiças de frango não curadas. A cor instrumental (chroma e hue), as propriedades sensoriais das linguiças não curadas A e B foram similares ao da linguiça comercial curada (C). Porém, a cor sensorial e a aparência das amostras A e B foram estatisticamente superiores às das linguiças comerciais não curadas $\mathrm{D}$, elaboradas sem a adição de nitrito ou pigmentos. Os resultados mostraram que é possível produzir linguiça de frango frescal não curada contendo reduzido teor de gordura com segurança e alta qualidade, utilizando pigmentos e antioxidantes naturais.

Palavras-chave: composição centesimal; cor instrumental; teste de aceitação; salmonella; clostridium.

\section{Introduction}

Cured sausages represent one of the main routes through which the meat industry can innovate and expand to increase profitability. Currently, sausages are the meat products most consumed in our country.

Sausages are an industrialized meat products obtained from the meat of butchering animals - with or without the addition of fat tissue, where ingredients are stuffed in casing (natural or artificial) and submitted to appropriate technological processes; their classification varies according to the manufacturing technology used (BRASIL, 2000).

Fresh sausages undergo no heat treatment to reduce the microflora and have high water activity. Thus, the addition of curing ingredients may increase the microbiological stability of these fresh products.

The curing process comprises the addition of salt and nitrate and/or nitrite (a reduced form of nitrate) and other ingredients necessary to chemically modify the physical, chemical and microbiological properties of meat products (SINDELAR et al., 2007).

Nitrite and/or sodium or potassium nitrate are responsible for the development of color, flavor and smell of cured products, they act as strong antioxidants and as powerful anti-microbial agents to control the growth of spores of Clostridium botulinum (SHAHIDI; PEGG, 1992). Nitrite is considered more important to the control of the microbiota than to the color control of the

Department of Exact and Earth Sciences, Federal University of São Paulo - UNIFESP, Rua Prof. Artur Riedel, 275, CEP 09972-270, Jd. Eldorado, Diadema, SP, Brazil,

e-mail: anna.venturini@unifesp.br

${ }^{2}$ Faculty of Food Engineering, Federal University of Grande Dourados - UFGD, Dourados, MS, Brazil

${ }^{3}$ Department of Agro-industry, Food and Nutrition, University of Sao Paulo - USP, Piracicaba, SP, Brazil

${ }^{4}$ Faculty of Food Engineering, Metropolitan University of Santos - UNIMES, Santos, SP, Brazil

${ }^{*}$ Corresponding author 
cured product (ROBERTS, 1975). However, it is already well documented that $\mathrm{N}$-nitroso compounds and nitrate induce tumor formation through its conversion into nitrite, an oxide destabilized, leading to an increase in the production of free radicals and to cell damage (DEMEYER et al., 2008).

The increasing interest of consumers for natural foods and for the so-called organic and/or free of preservatives foods has raised the demand for meat products made with uncured chicken meat, processed without the addition of nitrate/nitrite (SINDELAR et al., 2007). The color of the meat in natura and of products called fresh is extremely important. The four sensory attributes which determine the consumer's decision to purchase fresh meat products are: color, juiciness, flavor and texture/tenderness. Within these attributes, color is the first and most important factor at the moment of purchasing (ABERLE et al., 2001). Uncured products that do not include nitrate or nitrite in their formulation usually show undesirable appearance, smell and flavor (SINDELAR et al., 2007). In this context, two formulations of uncured fresh chicken sausage were tested using natural cochineal carmine dye and rosemary extracts or synthetic antioxidants - used to give color, appearance and pleasant flavor to products. Considering the increasing demand of consumers for healthier foods, sausages were processed with chicken raised in an alternative system, without the use of growth promoters and antibiotics. Fresh sausages were prepared with deboned chicken leg due to the surplus of this noble cut in the in natura chicken market, which occurs because of the consumers' preference for white breast meat (IBGE, 2008).

Therefore, the first objective of this preliminary experiment was to determine the centesimal composition, instrumental color and microbiological quality of uncured fresh chicken sausages prepared with reduced fat content $(10 \%)$ and different carmine concentrations, and also to verify whether there is a difference in the acceptance of color, tenderness, flavor and appearance between the uncured fresh sausages prepare for this experiment and the uncured and cured fresh chicken sausages commercially available.

\section{Materials and methods}

\subsection{Formulation and processing of sausages}

In a pilot scale and following the Good Manufacturing Practices, two experimental batches of uncured fresh chicken sausages called "A" and "B" were processed, according to formulations (\%) described in Table 1.

The processing of the sausages used meat and skin of chicken legs (Kórin ${ }^{\circledR}$, Ipeúna-SP), the meat and skin were ground in 8 and $12 \mathrm{~mm}$ disks, respectively. The ground skin and meat were transported to a mixer, where cool water and other ingredients were added. After mixing, the meat mass was stuffed in sheep casing and tied with cord in the desired size. The sausages were stored in cold chambers in the dark, at freezing temperature of approximately $-2{ }^{\circ} \mathrm{C}$ for 28 days.

\section{$2.2 p H$}

Five chicken meat and skin samples were collected for $\mathrm{pH}$ measurements immediately before processing. The $\mathrm{pH}$ of the uncured chicken sausages "A" and "B" were monitored through glass electrodes placed directly in the meat mass of mixed products.

\subsection{Centesimal composition analysis}

The moisture, protein and fat contents of uncured chicken sausages " $\mathrm{A}$ " and "B" were evaluated according to the AOAC methodology (1984).

\subsection{Microbiological analysis}

The evaluation of the microbiological quality of the uncured chicken sausages " $\mathrm{A}$ " and "B" was performed after 28 days of storage at $-2{ }^{\circ} \mathrm{C}$ through the determination of the Most Probable Number (MPN) of total and fecal coliforms per gram of food, the number of coagulase-positive staphylococci and sulfite-reducing Clostridium at $46^{\circ} \mathrm{C}$, and of the presence of Salmonella, since the presence of such groups or species in great amounts may indicate the exposure of food to conditions that may allow the multiplication of infectious or toxigenic species. The tests were performed according to methodology proposed by Vanderzant and Splittoesser (1992).

\subsection{Instrumental color}

The CIE $L^{\star} a{ }^{\star} b^{\star}$ values were obtained were obtained using a portable spectrophotometer $\left(\mathrm{D}_{65}, 10^{\circ}\right)$. The hue angle $\left[\left(\mathrm{b}^{*} / \mathrm{a}^{\star}\right) \tan ^{-1}\right]$ and saturation index $\left[\left(\mathrm{a}^{* 2}+\mathrm{b}^{* 2}\right)^{1 / 2}\right]$ of uncured chicken sausages "A" and "B" were also calculated.

\subsection{Sensory analysis}

This work was submitted to the Ethics Committee in Research of Metropolitan University of Santos - UNIMES and approved with number 017/09 as being in accordance with Resolution 196/96 of the National Health. The uncured chicken sausages "A" and "B" were compared with two other commercial brands of fresh chicken sausage: cured sausage " $\mathrm{C}$ " and uncured sausage " $D$ ". The sensory evaluation of products was performed by 35 consumers in individual booths at room temperature, using white light. The analyses of raw and fried samples were performed in three steps.

Table 1. Percentages of ingredients used in formulations of uncured fresh chicken sausages " $\mathrm{A}$ " and " $\mathrm{B}$ ".

\begin{tabular}{lcc}
\hline \multicolumn{1}{c}{ Ingredients and additives } & Sausage A (\%) & Sausage B (\%) \\
\hline Chicken leg & 82.2 & 82.2 \\
Skin & 10 & 10 \\
Water/ice & 3 & 3 \\
Salt (sodium chloride) & 0.3 & 0.3 \\
Glucono-delta-lactone (GDL) & 0.5 & 0.5 \\
Cochineal carmine & 0.01 & 0.05 \\
Seasoning for fresh sausage & 1.5 & 1.5 \\
Powder garlic & 0.15 & 0.15 \\
Maltodextrin & 1.5 & 1.5 \\
Synthetic antioxidant & - & 0.25 \\
Rosemary extract & 0.4 & - \\
Red pepper & 0.2 & 0.2 \\
\hline
\end{tabular}


First, for the sensory evaluation of color and appearance of raw sausages (before frying), it was used the preference ranking, whose principle is the preference that consumers show for a product over another. The uncured chicken sausages were thawed in refrigerator for approximately 24 hours for temperature balance. The samples were served in disposable white plastic cups, identified by three-digit numbers, randomly arranged. The samples were presented in complete blocks, after 28 days of freezing and observation of good microbiological quality. The results were statistically analyzed by means of the table for the ordering test of Newell and Mac Farlane, which defines the value of critical differences between the total ordering at level of 5\% (NEWELL; MAC FARLANE, 1987).

Shortly after, color, flavor, tenderness and overall appearance of fried sausages were evaluated using a nine-point hedonic scale, where the extremes corresponded to $9=$ liked extremely, 8 = liked very much, 7 = liked moderately, $6=$ liked slightly, $5=$ neither liked nor disliked, $4=$ disliked slightly, $3=$ disliked moderately, 2 = disliked much, and 1 = disliked extremely.

The purchase intention of fresh products was assessed by a 5 -point scale where $1=\mathrm{I}$ would certainly buy, $2=\mathrm{I}$ would probably buy, 3 = maybe I would buy / not buy, $4=$ I would probably not buy, and $5=$ I would certainly not buy.

\subsection{Statistical analysis}

The analysis of variance (ANOVA) and Tukey's test for comparisons between products were elaborated and those commercially available were performed using the Statistic software, version 6. All experiments were repeated twice with three replications per experiment.

\section{Results and discussion}

\subsection{Centesimal composition}

The average moisture, protein fraction and fat fraction contents of uncured chicken sausages were 73\%, 19\% and 7.3\% respectively. The current legislation states that fresh-type sausages should present in their physicochemical characteristics $70 \%$ maximum moisture content, $30 \%$ maximum fat content and $12 \%$ minimum protein content (BRASIL, 2003). Comparing the results obtained with the limits set by law, it could be observed that the protein content was significantly higher than the maximum limit, whereas the moisture content was slightly over $70 \%$. These results reflect a compensation pattern between moisture, protein and fat levels, where a slight increase of moisture as a function of reduced fat content of the final product can be observed, which was similar to the chicken leg with skin.

Current law (BRASIL, 1998) defines as "reduced fat content", the product which has a minimum fat reduction of $25 \%$ when compared to the conventional product; and as "low fat content", when the fat content is lower than $3 \%$ in solid products. In this work, chicken sausages made only with fat from the leg skin (A and B) were considered as having reduced fat content, since they presented reduction of $41.95 \%$ ( $7.3 \%$ of fat), when compared to conventional products made with chicken meat, which have about $17.4 \%$ of fat before frying (NEPA, 2006).

\section{$3.2 \mathrm{pH}$}

The average $\mathrm{pH}$ of meat and chicken skin were 6.47 and 6.25 , respectively. During storage under freezing, the $\mathrm{pH}$ of uncured sausages $\mathrm{A}$ and $\mathrm{B}$ decreased significantly over time $(p<0.05)$, as shown in Figure 1. The rapid decline in $\mathrm{pH}$ after 24 hours of storage was probably due to the conversion of glucono-delta-lactone into gluconic acid. The $\mathrm{pH}$ may interact with other factors such as water activity, salt, temperature, oxide-reduction potential, and preservatives to inhibit growth of pathogenic microorganisms and deteriorate the microflora (FACTORS..., 2003). In addition to interfering in acidity, glucono-delta-lactone can also act as flavoring, making the final product tastier.

\subsection{Microbiological evaluation}

The microbiological evaluation carried out after 28 days of storage showed that the bacterial counting of the uncured chicken sausages $A$ and $B$, prepared without the addition of nitrite, was within the limits established by the Brazilian legislation (BRASIL, 2001).

The most probable number (MPN) of total coliforms ranged from $4.3 \times 10$ for sausage "A" to $9.3 \times 10$ for sausage " $\mathrm{B}$ ", while the MPN for E. coli was 3.0 MPN.g-1 of product for both products. The counting of sulphite-reducing Clostridium was $<10$ CFU.g-1 ${ }^{-1}$ for both sausages ("A" and "B"). The counting of coagulase-positive staphylococci was $1.5 \times 10^{2}$ for sausage " $\mathrm{A}$ " and $<10$ CFU.g g $^{-1}$ for sausage " $B$ ". The presence of Salmonella was not observed in the assessed samples.

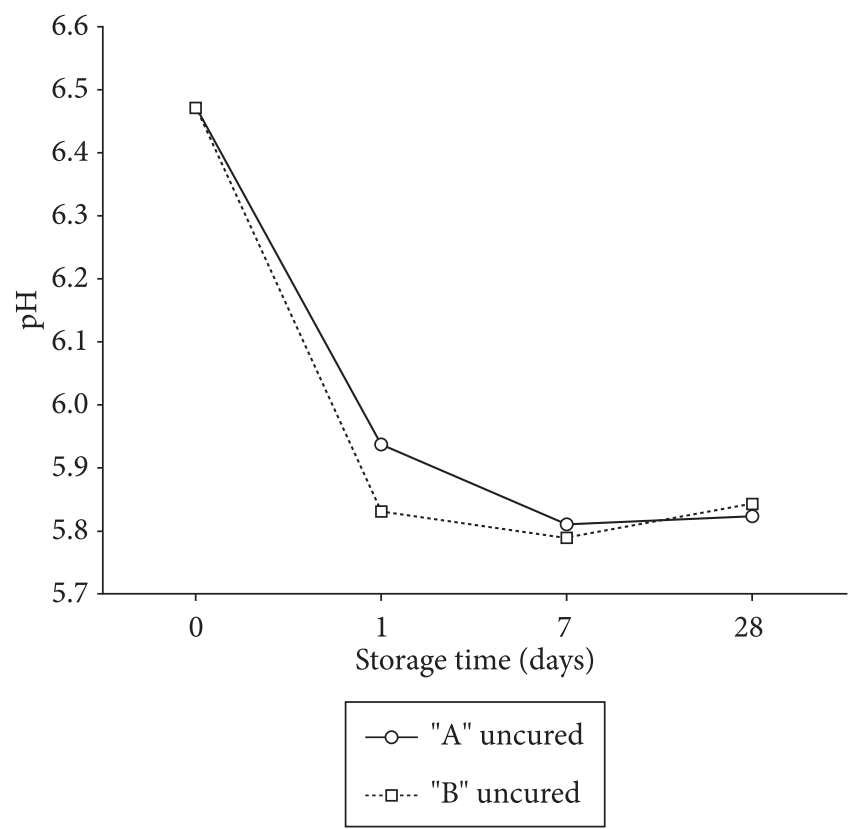

Figure 1. pH values of the uncured sausages "A" and "B" over 28 days of storage. 


\subsection{Instrumental evaluation}

Table 2 shows the averages of instrumental color of raw fresh chicken sausages.

The color saturation ( $\mathrm{C}^{*}$ value) of the uncured sausage "A" was significantly lower than that of the uncured sausage "B", whose saturation was similar to that of the commercial cured sausage (C). The $\mathrm{h}^{\star}$ value (hue) of uncured sausage " $\mathrm{B}$ ", which received a higher concentration of carmine extract, was significantly lower than the other formulations. The greater darkening of product $\mathrm{D}$, in comparison to the other samples, may be correlated both to the absence of antioxidant as well as to the absence of nitrite or carmine, to stabilize the myoglobin responsible for the pink coloration, typical of products made with chicken meat. Lee, Hendricks and Cornforth (1999) observed that the reducing effect of antioxidants inhibits the formation of metamyoglobin, responsible for the darkening of the red color in meat products. Later, Yu et al. (2002) concluded that natural extracts can have antioxidant effect comparable to synthetic antioxidants in the maintenance of color and prevention of lipid oxidation in products prepared with chicken meat during refrigerated storage at $2{ }^{\circ} \mathrm{C}$.

The effect of high cochineal carmine concentration in sample B can be clearly observed by the high values of red $\left(\mathrm{a}^{*}\right)$ and chroma $\left(C^{*}\right)$, which were significantly higher than the other samples, except for product $\mathrm{D}$, which showed saturation index of the color $\left({ }^{*} \mathrm{C}\right)$ comparable to that of samples A.

\subsection{Sensory evaluation}

The results obtained in the preference ranking test of consumers are presented in Table 3 and the descending order (from the most preferred to the least preferred) established for the color and appearance attributes of raw chicken sausages were respectively: $\mathrm{C}>\mathrm{A}>\mathrm{B}>\mathrm{D}$ and $\mathrm{C}=\mathrm{A}>\mathrm{B}>\mathrm{D}$.

Although statistically significant, no differences were found $(p<0.05)$ between the evaluated samples, the color and overall appearance of commercial cured sausage, added of nitrate/nitrite, were the most preferred; while the color and overall appearance of commercial uncured sausages were the least preferred, suggesting that the main factor for the ordering of the raw sausages was the perception of the color oxidation in the product, which was more evident in sample $\mathrm{D}$, as shown in Table 1. The significant lower saturation of red color $\left(<\mathrm{C}^{\star}\right)$ and the increased tone of brown $\left(>h^{*}\right)$ confirm that these samples had more noticeably oxidized color.

The scores of the Acceptance Test provided more definitive answers on the differences between the samples. Table 4 shows the average scores assigned by tasters for the color, flavor, tenderness and overall appearance attributes of fresh chicken sausages.

The scores awarded for the sensory color, tenderness, flavor and overall appearance of uncured sausages "A" and "B", prepared without the addition of nitrate/nitrite, did not differ significantly from the scores awarded to the commercial sausages prepared with nitrite $(\mathrm{C})$. However, the sensory color and overall appearance of samples "A" and "B" were statistically higher than those of commercial uncured sausages "D", also prepared without the addition of nitrite. This difference may be related to the absence of carmine and antioxidant in the formulation of the commercial uncured product, which may have adversely affected the color, flavor and appearance of the products during storage due to the oxidation of oxymyoglobin (red) into metamyoglobin (brown).

No differences were found for the attribute flavor between uncured sausages A and B and commercial cured sausage C. The panelists indicated that the formulation with reduced fat was similar to the commercial cured sausage in terms of acceptability, thus suggesting that the lipid content was not the main decision factor.

Despite the sensory differences between sausages A, B, C and $\mathrm{D}$, none of the scores were extremely low, indicating that all products could be considered acceptable by most consumers. However, in the purchase intention test (Table 5), $61 \%$ of

Table 2. Averages ${ }^{\star}$ of instrumental color $(n=5)$ of raw fresh sausages (before frying process) for the color, flavor, tenderness and overall appearance attributes after 28 days of storage at $-2{ }^{\circ} \mathrm{C}$.

\begin{tabular}{|c|c|c|c|c|c|}
\hline \multirow[t]{2}{*}{ Fresh chicken sausage } & \multicolumn{5}{|c|}{ Instrumental color $^{1}$} \\
\hline & $\mathrm{L}^{*}$ & $a^{*}$ & $b^{*}$ & $\mathrm{C}^{*}$ & $\mathrm{~h}^{*}$ \\
\hline "A" uncured & $51.2 \pm 0.8^{\mathrm{b}}$ & $8.7 \pm 0.6^{b}$ & $7.9 \pm 1.1^{\mathrm{b}}$ & $11.75 \pm 1.1^{\mathrm{b}}$ & $41.90 \pm 2.8^{\circ}$ \\
\hline "B" uncured & $42.9 \pm 1.7^{\mathrm{a}}$ & $18.6 \pm 0.8^{\mathrm{a}}$ & $3.8 \pm 0.9^{\mathrm{a}}$ & $18.98 \pm 1.0^{\mathrm{a}}$ & $11.58 \pm 2.2^{\mathrm{b}}$ \\
\hline "D" commercial uncured & $47.9 \pm 2.2^{\mathrm{c}}$ & $3.2 \pm 0.9^{\mathrm{d}}$ & $8.4 \pm 2.1^{\mathrm{b}}$ & $9.05 \pm 1.9^{c}$ & $68.31 \pm 7.8^{\circ}$ \\
\hline
\end{tabular}

${ }^{1}$ Averages in the same column with different letters are statistically different $(p<0.05)$.

Table 3. Sum of values obtained in the preference ranking test for raw fresh chicken sausages (before frying).

\begin{tabular}{lcc}
\hline Fresh chicken sausage & \multicolumn{2}{c}{ Sensory atributes } \\
\cline { 2 - 3 } & Color & Appearance \\
\hline "A" uncured & $47^{\mathrm{a}}$ & $50^{\mathrm{a}}$ \\
"B" uncured & $44^{\mathrm{a}}$ & $45^{\mathrm{a}}$ \\
"C" commercial cured & $54^{\mathrm{a}}$ & $50^{\mathrm{a}}$ \\
"D" commercial uncured & $35^{\mathrm{a}}$ & $35^{\mathrm{a}}$ \\
\hline
\end{tabular}

${ }^{1}$ Averages in the same column with different letters are statistically different $(p<0.05)$. 
Table 4. Averages of the sensory scores $(n=35)$ of fresh fried sausages for the color, flavor, tenderness and overall appearance attributes after 28 days of storage at $-2{ }^{\circ} \mathrm{C}$.

\begin{tabular}{|c|c|c|c|c|}
\hline \multirow[t]{2}{*}{ Fresh chicken sausage } & \multicolumn{4}{|c|}{ Sensory attributes $^{1}$} \\
\hline & Color & Tenderness & Flavor & Appearance overall \\
\hline "A" uncured & $6.8 \pm 1.8^{\mathrm{a}}$ & $7.3 \pm 1.5^{\text {a.b }}$ & $7.1 \pm 1.7^{\text {a.b }}$ & $7.1 \pm 1.4^{\mathrm{a}}$ \\
\hline "B" uncured & $6.8 \pm 1.7^{\mathrm{a}}$ & $7.8 \pm 1.2^{\mathrm{a}}$ & $7.4 \pm 1.3^{\mathrm{a}}$ & $7.1 \pm 1.4^{\mathrm{a}}$ \\
\hline "D" commercial uncured & $6.0 \pm 2.0^{\mathrm{b}}$ & $6.4 \pm 1.9^{\mathrm{b}}$ & $6.0 \pm 2.1^{\mathrm{b}}$ & $5.8 \pm 2.1^{\mathrm{b}}$ \\
\hline
\end{tabular}

${ }^{1}$ Averages in the same column with different letters are statistically different $(p<0.05)$.

Table 5. Percentage of consumers who participated in the tests according to ranges of purchase intention.

\begin{tabular}{|c|c|c|c|c|}
\hline & & & "C" commercial & "D" commercial \\
\hline & "A" uncured & "B" uncured & cured & uncured \\
\hline I would certainly buy & 22.6 & 29.0 & 26.6 & 19.4 \\
\hline I would probably buy & 38.7 & 32.2 & 43.3 & 9.7 \\
\hline I would maybe buy / not buy & 25.8 & 29.0 & 20.0 & 38.7 \\
\hline I would probably not buy & 12.9 & 6.5 & 10.0 & 32.3 \\
\hline I would certainly not buy & 0.0 & 3.2 & 3.3 & 0.0 \\
\hline
\end{tabular}

consumers responded that they would certainly or probably buy the uncured sausages "A" and "B", while only $29 \%$ responded they would buy the commercial uncured sausage " $D$ ".

The lower carmine concentration and the addition of natural antioxidant prevented the darkening of product $\mathrm{A}$, which showed the same acceptance level of the commercial cured sausage C. Although sausage " $A$ " presented the same acceptance with no statistical differences, which from sausage " $B$ " in all sensory attributes evaluated product " $B$ " had the highest intensity of red color before frying, due to the higher concentration of cochineal carmine pigment, was rejected by some consumers, who expected a brighter red color in products prepared with chicken meat.

\section{Conclusions}

The results obtained in this preliminary work show that it is possible to produce safe and high-quality fresh meat products without the addition of nitrite, using natural antioxidants and pigments. However, additional research is needed to conclusively determine the antioxidant effect of rosemary extract on cochineal carmine. It should be emphasized that the quality of the final product depends on the implementation of Good Manufacturing Practices and a strict temperature control throughout the cold chain, including in the consumers' homes, with clear and precise information about the storage temperature and how to thaw and prepare these products on the packaging labels.

\section{Acknowledgements}

The authors are grateful to 'Kórin Agricultura Natural' for generously providing the meat samples.

\section{References}

ABERLE, E. D. et al. Principles of Meat Science. 4th ed. Iowa: Kendall/Hunt, 2001.
BRASIL. Agência Nacional de Vigilância Sanitária. Portaria no 27, de 13 janeiro de 1998. Aprova o Regulamento Técnico referente à Informação Nutricional Complementar. Diário Oficial da República Federativa do Brasil, Brasília, DF, 16 jan. 1998. Seção 1, pt.1. Disponível em: <http://e-legis.anvisa.gov.br/leisref/public/ showAct.php>.

BRASIL. Agência Nacional de Vigilância Sanitária. Instrução Normativa $\mathrm{n}^{\circ} 4$, de 31 de março de 2000 . Regulamento Técnico de Identidade e Qualidade de Lingüiça. Diário Oficial da República Federativa do Brasil, Brasília, DF, 5 abr. 2000. Disponível em: $<$ http://extranet.agricultura.gov.br/sislegis-consulta/servlet/ VisualizarAnexo?id=1640>

BRASIL. Agência Nacional de Vigilância Sanitária. Resolução - RDC n ${ }^{\circ}$ 12, de 2 de janeiro de 2001. Regulamento Técnico sobre os padrões microbiológicos para alimentos. Diário Oficial da República Federativa do Brasil, Brasília, DF, 10 jan. 2001. Disponível em: $<$ http://www.anvisa.gov.br/legis/resol/12_01rdc.htm>.

ASSOCIATION OF OFFICIAL ANALITICAL CHEMISTS - AOAC. Official methods of analysis. 14th ed. Washington: AOAC, 1984.

DEMEYER, D.; HONIKEL, K.; DE SMET, S. A challenge for the meat processing industry. Meat Science, v. 80, n. 4, p. 953-959, 2008. http://dx.doi.org/10.1016/j.meatsci.2008.06.003

FACTORS that Influence Microbial Growth. Comprehensive Reviews in Food Science and Food Safety, v. 2, p. 21-32, 2003. Supplement. http://dx.doi.org/10.1111/j.1541-4337.2003.tb00048.x

INSTITUTO BRASILEIRO DE GEOGRAFIA E ESTATÍSTICA - IBGE. Sistema IBGE de Recuperação Automática - SIDRA. Rio de Janeiro: IBGE, 2008. Disponível em: <http://www.sidra.ibge.gov.br>.

LEE, B. J.; HENDRICKS, D. G.; CORNFORTH, D. P. A comparison of carnosine and ascorbic acid on color and lipid stability in a ground beef pattie model system. Meat Science, v. 51, n. 3, p. 245-253, 1999. http://dx.doi.org/10.1016/S0309-1740(98)00121-1

NEWELL, G. J.; Mac FARLANE, J. D. Expanded tables for multiple comparison procedures in the analysis of ranked data. Journal of Food Science, v. 52, n. 6, p. 1721-1725, 1987. http://dx.doi. org/10.1111/j.1365-2621.1987.tb05913.x

ROBERTS, T. A. The microbial role of nitrite and nitrate. Journal of the Science of Food and Agriculture, v. 26, n. 11, p. 1755-1760, 1975. http://dx.doi.org/10.1002/jsfa.2740261118 
SHAHIDI, F.; PEGG, R. B. Nitrite-free meat curing systems: update and review. Food Chemistry, v. 43, n. 3, p. 185-191, 1992. http:// dx.doi.org/10.1016/0308-8146(92)90171-W

SINDELAR, J. J. et al. Investigating quality attributes and consumer acceptance of uncured, no-nitrate/nitrite-added commercial hams, bacons, and frankfurters. Journal of Food Science, v. 72, n. 8, p. S551-S559, 2007a. PMid:17995620. http://dx.doi.org/10.1111/ j.1750-3841.2007.00486.x

SINDELAR, J. J. et al. Effects of vegetable juice powder concentration and storage time on some chemical and sensory quality attributes of uncured, emulsified cooked sausages. Journal of Food Science, v. 72, n. 5, p. S324-S332, 2007b. PMid:17995750. http://dx.doi. org/10.1111/j.1750-3841.2007.00369.x
Núcleo de Estudos e Pesquisa em Alimentos - NEPA. Tabela brasileira de composição de alimentos - TACO. Versão 2. 2. ed. Campinas, SP: UNICAMP, 2006. Disponível em: <http://www.unicamp.br/ nepa/taco/contar/taco_versao2.pdf>. Acesso em: jul. 2009.

VANDERZANT, C.; SPLITTOESSER, D. F. Compendium of methods for the microbiological examination of foods. 3th ed. Washington: American Public Health Association, 1992.

YU, L. et al. Rosemary extracts as inhibitors of lipid oxidation and color change in cooked turkey products during refrigerated storage. Journal of Food Science, v. 67, n. 2, p. 582-585, 2002. http://dx.doi. org/10.1111/j.1365-2621.2002.tb10642.x 